\title{
CCAAT/Enhancer Binding Protein Epsilon
}

National Cancer Institute

\section{Source}

National Cancer Institute. CCAAT/Enhancer Binding Protein Epsilon. NCI Thesaurus. Code C17900.

CCAAT/enhancer-binding protein epsilon ( $281 \mathrm{aa}, \sim 31 \mathrm{kDa}$ ) is encoded by the human CEBPE gene. This protein plays a role in transcriptional regulation. 